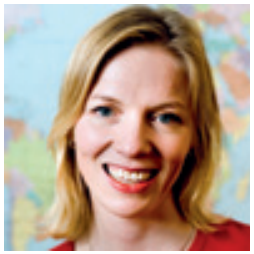

\title{
Kunsten å redde en mamma
}

\section{Det er alltid trist når mammaer $d \varnothing r$} fra barna sine. Det er i tillegg svært opprørende når vi vet at så mange dør helt unødvendig. Vi som har kommet langt på dette området, må bruke vår kunnskap og erfaring for å hjelpe land som har langt igjen. Samtidig er vi helt avhengig av å forstå de lokale utfordringene dersom vi skal få til noe som helst.

Jeg var i Niger i fjor sommer. Der dør hver syvende kvinne i forbindelse med graviditet og fødsel. En av syv. Det er et tall det er vanskelig å forstå. Hvert år dør over en halv million kvinner i forbindelse med graviditet og barnefødsel i verden. Mer enn $80 \%$ av dødsfallene kommer av blødninger, svangerskapsforgiftning, utrygge aborter og andre forhold som i Norge behandles rutinemessig ved et sykehus. De aller fleste av disse kvinnene kunne blitt reddet dersom de hadde fått tilgang til helsetjenester som vi tar som en selvfølge.

I Niger og i mange andre land der CARE jobber, synes det fortsatt å være slik at en kvinnes liv ikke anses som like verdifullt som en manns. Dermed blir heller ikke hennes helse prioritert. Hvis en av syv i Niger ble drept av opprørere eller tørke, ville dette ha kommet øverst på den politiske agendaen. Å dø i barsel er en risiko kvinner må akseptere i stillhet.

I tillegg til at det er uholdbart i seg selv at så mange kvinner rammes av en smertefull og unødvendig død, har det store konsekvenser for de barna som blir igjen når mamma dør. Vår erfaring er at særlig døtrene rammes, i form av underernæring og manglende skole- gang hvis de må vokse opp hos slektninger. For å sikre at jentene får en bedre fremtid, er det avgjørende at mødrene får overleve.

FN regner med at en fjerdedel av graviditeter er uønsket, og at en av tre dødsfall kunne vært unngått hvis kvinnen hadde hatt tilgang til prevensjon. Mange kvinner vet ikke om moderne prevensjonsformer, eller har ikke tilgang til dem. I mange land har unge kvinner ikke tilgang til slike tjenester før de blir gift, av religiøse eller «moralske» årsaker. Og mange får ikke lov av ektemannen til å bruke det, fordi han vil ha mange barn. All forskning og folkevett viser at abort ikke forsvinner når den blir forbudt, det fører bare til at det gjøres i det skjulte - og med større risiko.

I de fattigste landene skjer halvparten av fødslene uten kvalifisert hjelp av noe slag. Mange møter frykten og smertene alene i hjemmet. Det aller viktigste for å redusere dødstallene er å ha kvalifisert helsepersonell til stede når kvinner føder.

Første skritt er å få kvinnene og familiene deres til selv å forstå at kvinnene bør føde på klinikk. Dette er ikke så selvsagt i Niger som i Norge. Manglende kunnskap og forståelse er en viktig årsak. Dårlig behandling på sykehuset er en annen.

En undersøkelse fra Zimbabwe viste at $20 \%$ av kvinnene opplever å bli slått av helsepersonell under fødsel. Det er nok ekstremt, men de fleste sykehus i fattige land sliter med underbemanning, lite penger og lite oppfølging.

Dessuten må man ofte betale for tjenestene, enten offisielt eller pga. korrupsjon, og selv ta med seg det man trenger av medisiner, utstyr og mat. Forskning viser at selv de aller fattigste er villige til å betale litt, hvis de får bra behandling og på forhånd vet hva det vil koste.
For å sikre at ingen flere gravide kvinner dør unødvendig, må vi gjøre flere ting på en gang. Det mest effektive er jo å sørge for at de aller fleste føder på klinikk. Men det hjelper lite å starte klinikker hvis ikke kvinnene finner en bil, motorsykkel eller sykkel å komme seg dit med. Det hjelper også lite å bygge sykehus hvis det ikke finnes leger eller jordmødre. Vi kommer ikke i mål ved å utdanne jordmødre hvis helsesektoren ikke har penger til å ansette dem. Det hjelper lite å overtale myndighetene til å gi gratis helsetjenester hvis de ansatte ikke får betalt og må ty til korrupsjon. Og vi kommer ingen vei med abortklinikker hvis kvinnene ikke tør gå dit av frykt for å bli angrepet. Og så videre. God mødrehelse er en kunst som krever at man ser sammenhengen mellom kulturelle, økonomiske, sosiale og medisinske hensyn.

Vi må derfor jobbe på flere fronter. CARE arbeider mye med å styrke kvinnenes økonomiske posisjon i familiene og øke deres kunnskap både om helse og om rettigheter. Fortsatt er det slik at mange kvinner ikke har mulighet til å velge om og når de blir gravide. Altfor få har tilgang til trygg abort og grunnleggende gynekologisk behandling. Mange har ikke mulighet til å bestemme hvordan familiens penger skal brukes, selv når det er snakk om livsviktig medisinsk behandling.

Vår erfaring er at når kvinnene får økt kunnskap og økt økonomisk trygghet, kan de i langt større grad være med på å bestemme over sin egen fremtid, og sørge for at de ikke dør i forbindelse med graviditet.

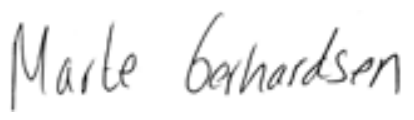

I neste nummer:
Karkirurgi

Aortaaneurismer

Hjemmerespirator
Borreliose

Omega-3 og hjertesykdom

Genetikk ved kols 